\title{
Carbon based materials as novel redox mediators for dye wastewater biodegradation
}

\author{
R.A. Pereira ${ }^{a}$, M.F.R. Pereira ${ }^{\text {b }}$, M.M. Alves ${ }^{a}$, L. Pereira ${ }^{a}, *$ \\ a IBB-Instituto Biotecnologia e Bioengenharia, Centro Engenharia Biológica, Universidade do Minho, Campus de Gualtar, 4710-057 Braga, Portugal \\ ${ }^{\mathrm{b}}$ Laboratório de Catálise e Materiais (LCM), Laboratório Associado LSRE/LCM, Departamento de Engenharia Química, Faculdade Engenharia da \\ Universidade do Porto, Rua Dr. Roberto Frias, 4200-465 Porto, Portugal
}

\section{A R T I C L E I N F O}

\section{Article history:}

Received 3 April 2013

Received in revised form 11 June 2013

Accepted 1 July 2013

Available online $\mathrm{xxx}$

\section{Keywords:}

Azo dyes

Activated carbon

Carbon xerogel

Carbon nanotubes

Reduction

\begin{abstract}
A B S T R A C T
Due to their large-scale production and extensive application, dyes have turned serious pollutants when improperly handled and disposed, creating grave public health and environmental problems. One of the problems that textile industry is facing is related with the incomplete exhaustion of dyes onto textile fibres from an aqueous dyeing process, and the need to implement innovative and sustainable effluent treatment methods to remove colour. Additionally, legislation on the limits of colour discharge has turn increasingly rigid. Biological treatment systems have been shown as promising technologies. The main limiting factor of the reductive transformations by anaerobic sludge is the electron transfer, a slow process. This limitation can be overcome by making use of redox mediators, which are compounds that accelerate the electron transfer from a primary electron donor to a terminal electron acceptor, to speed up the process. Activated carbon $(A C)$ has been shown as a feasible redox mediator. Samples of microporous thermal treated $\mathrm{AC}\left(\mathrm{AC}_{\mathrm{H} 2}\right)$ and mesoporous carbons: xerogels ( $\left.\mathrm{CXA}, \mathrm{CXB}\right)$ and carbon nanotubes (CNT) were tested on azo dye and textile wastewater biodegradation. $~ 85 \%$ Mordant Yellow 10 (MY10) and 70\% of Reactive Red 120 (RR120) colour removal was obtained with all the carbon materials. Acid Orange 10 (AO10) is not biodegraded in the absence of carbon materials, but with CXB and CNT a 98\% of colour removal was achieved. For MY10 and RR120, rates increased in the order: control $<\mathrm{AC}_{\mathrm{H} 2}<\mathrm{CXA}<\mathrm{CXB}<\mathrm{CNT}$. HPLC analysis confirmed the reduction of dyes with the formation of corresponding aromatic amines. The effect of CNT was also observed in the biological treatment of real textile wastewaters.
\end{abstract}

(C) 2013 Elsevier B.V. All rights reserved.

\section{Introduction}

Textile industry faces a problem related to the incomplete exhaustion of dyes onto textile fibres, during the aqueous dyeing process, and needs to implement innovative and sustainable effluent treatment processes to remove colour. Azo compounds are molecules with one or more azo $(-\mathrm{N}=\mathrm{N}-)$ bridges, linking substituted aromatic structures, and constitute the largest and most diverse group of dyes and pigments used in commercial applications $[1,2]$. Discharge of azo dyes is undesirable because, apart from the aesthetic point of view, some of them and their breakdown products are toxic towards aquatic life and mutagenic for humans $[1,3,4]$. Conventional physical and chemical techniques can be used efficiently to remove dyes from textile wastewater. However, these methods are quite expensive, have operational problems and generate huge quantities of sludge [5-7]. Biological

\footnotetext{
* Corresponding author. Tel.: +351253601963.

E-mail address: lucianapereira@deb.uminho.pt (L. Pereira).
}

treatment of textile wastewater is an economic alternative and has shown better efficiency than physico-chemical methods, with remarkable results [9-11]. Mixed culture activated sludge processes and, more recently, other biological processes involving anaerobic transformations, have been developed for efficient removal of dyes [12]. However, reductive transformation of many recalcitrant compounds proceeds very slowly, leading to poor performance of bioreactors (need of long retention times to reach a satisfactory extent) [13]. Redox mediators are compounds that can be reversibly oxidised and reduced, thereby conferring the capacity to serve as electron carriers in multiple redox reactions, increasing the reaction rates by one or more orders of magnitude [14]. Activated carbon (AC) has been shown to be a feasible redox mediator presenting advantages in comparison with soluble ones (ex. anthraquinone-disulphonate and anthraquinone2-sulphonate) [15-17]. In addition, those carbon materials have the possibility of being modified in order to take advantages of their unique specific proprieties. Recently, Pereira et al. [16] have demonstrated the role of surface chemistry of activated carbon in the catalysis of chemical and biological reduction of dyes, by 
<smiles>O=C(O)c1cc(N=Nc2ccc(S(=O)(=O)O[Na])cc2)ccc1O</smiles>

Mordant Yellow 10 (MY10)<smiles>O=S(=O)(O[Na])c1cc(O)c2c(/N=N/Nc3ccccc3)c(O)ccc2c1</smiles>

Acid Orange 10 (AO10)

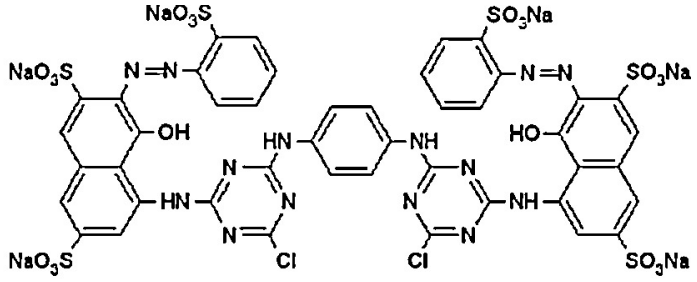

Reactive Red 120

(RR120)

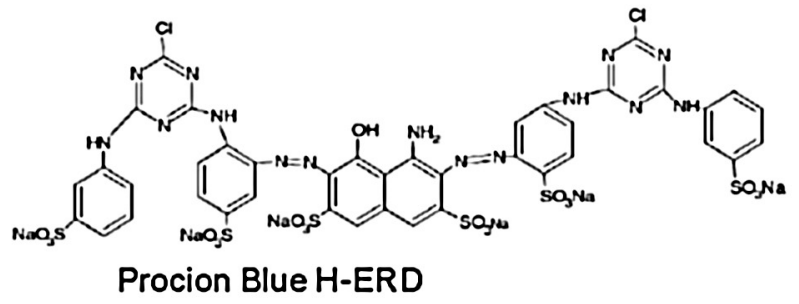<smiles>COc1cc2cc(O[Na])cc(Nc3nc(Cl)nc(NCc4ccc(CC(N)=O)cc4)n3)c2c(O)c1N=Nc1ccc2ccccc2c1O</smiles>

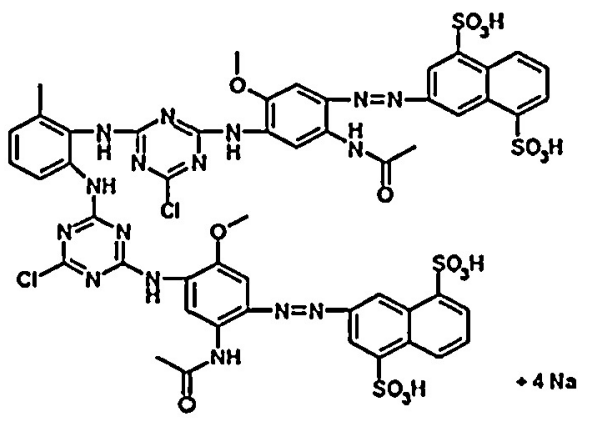

Procion Yellow H-EXL

\section{Procion Red H-EXL}<smiles>Nc1ccc(C(=O)O[Na])cc1</smiles>

Sulfanilic acid

(SA)<smiles>Nc1ccc(O)c(C(=O)O)c1</smiles>

5-Aminosalicylic acid

(5-ASA)

Fig. 1. Molecular structure of azo dyes and aromatic amines.

testing a set of carbon samples which were prepared by chemical and thermal modifications of the same commercial activated carbon. However, activated carbons are generally microporous, with low macropore or mesopore volumes, which can induce diffusion limitations during the catalytic and adsorptive processes. The use of carbon xerogels (CX) and carbon nanotubes (CNT) as catalysts for organic pollutants degradation has been demonstrated before $[18,19]$. These new mesoporous materials may present technological advantages as new shape catalyst mainly for large molecules (e.g. azo dyes) degradation. Carbon xerogels present excellent properties, such as high specific surface area, porosity and conductivity and controllable average pore size, which can be customised for the final applications.

In the present study, the mesoporous materials, CX and CNT, were studied for the first time as redox mediators on anaerobic dye reduction and compared with the microporous thermal modified activated carbon, $\mathrm{AC}_{\mathrm{H} 2}$. Three azo dyes from different classes (mordant, reactive and acid) were tested: Mordant Yellow 10, Reactive Red 120 and Acid Orange 10. Biodegradation of real textile wastewaters was also investigated.

\section{Experimental}

\subsection{Chemicals}

Mordant Yellow 10 (MY10, dye content 85\%), Reactive Red 120 (RR120, dye content 50\%) and Acid Orange 10 (AO10, dye content $90 \%$ ) were purchased from Sigma and used without additional purification. Stock solutions of $15 \mathrm{mM}$ were prepared in deionised water. Aromatic amines were also purchased from Sigma at the 
highest analytic grade purity commercially available. Chemical structures of dyes and aromatic amines are illustrated in Fig. 1. The chemicals used to prepare the macronutrients solution were purchase from Sigma or Fluka at highest analytic grade purity commercially available. The solvents acetonitrile and acetic acid for HPLC analysis were purchased from Panreac.

\subsection{Preparation and characterisation of carbon materials}

Different sets of catalysts were prepared: thermal treated activated carbon $\left(\mathrm{AC}_{\mathrm{H} 2}\right)$, carbon xerogels $(\mathrm{CX})$ and multiwall carbon nanotubes (CNT).

To prepare the sample $\mathrm{AC}_{\mathrm{H} 2}$, a commercial NoritROX0.8 activated carbon (AC), which is an extruded acid washed activated carbon, with cylindrical pellets of $0.8 \mathrm{~mm}$ diameter and $5 \mathrm{~mm}$ length, was firstly chemical oxidised with $6 \mathrm{M}$ of $\mathrm{HNO}_{3}$ at boiling temperature for $3 \mathrm{~h}$, followed by thermal treatment under $\mathrm{H}_{2}$ flow at $700^{\circ} \mathrm{C}$ for $1 \mathrm{~h} \mathrm{[16]}$. The synthesis of the carbon xerogels (CX) consisted in the polycondensation of resorcinol (99\%, Aldrich) with formaldehyde (37\%, Aldrich) at an initially controlled $\mathrm{pH}$ [19]. Samples were synthesised by the sol-gel process at pH 6.25 (CXA) and 5.45 (CXB) in order to obtain materials with different textural properties. After setting the $\mathrm{pH}$ of the sol-gel process with $\mathrm{NaOH}$ solutions, polymerisation was carried out at $85^{\circ} \mathrm{C}$ during 3 days. Then, the gel was ground and dried in an oven during 4 days (first day at $60^{\circ} \mathrm{C}$, second day at $80^{\circ} \mathrm{C}$, third day at $100^{\circ} \mathrm{C}$ and fourth day at $120^{\circ} \mathrm{C}$ ). After that, the material was carbonised under nitrogen flow at $800^{\circ} \mathrm{C}$, using the following temperature programme: from room temperature to $150{ }^{\circ} \mathrm{C}$ (hold $2 \mathrm{~h}$ ), than to $400^{\circ} \mathrm{C}$ (hold $1 \mathrm{~h}$ ), further to $600^{\circ} \mathrm{C}$ (hold $1 \mathrm{~h}$ ) and to $800^{\circ} \mathrm{C}$ (hold $6 \mathrm{~h}$ ), in all steps at increments of $2{ }^{\circ} \mathrm{C} \mathrm{min}^{-1}$. Materials were finally cooled down to room temperature.

The textural characterisation of the materials was based on the corresponding $\mathrm{N}_{2}$ equilibrium adsorption/desorption isotherms, determined at $-196^{\circ} \mathrm{C}$ with a Quantachrome Instruments NOVA 4200 e apparatus [19]. BET surface areas $\left(S_{\mathrm{BET}}\right)$, mesoporous surface areas $\left(S_{\neq \mu \text { pores }}\right)$, micropore volumes $\left(V_{\mu \text { pores }}\right)$ and average mesopore diameters were obtained by the Barret, Joyner and Halenda $(\mathrm{BJH})$ method. The morphology and the semi-quantitative elemental analysis of the catalysts were attained by scanning electron microscopy (SEM) and energy dispersive X-ray spectroscopy (EDS), respectively, in a JEOL JSM 35C/Noran Voyager system. XRD spectra were recorded on a Philips X'Pert MPD diffractometer $(\mathrm{Cu}$ $\mathrm{K} \alpha=0.15406 \mathrm{~nm})$.

A commercial MWCNT sample (Nanocyl 3100) was also tested. According to the supplier, it has an average diameter of $9.5 \mathrm{~nm}$, an average length of $1.5 \mu \mathrm{m}$ and carbon purity higher than $95 \%$. Tessonnier et al. [20] characterised this material as having an average inner and outer diameters of 4 and $10 \mathrm{~nm}$, respectively. In the same work, it was observed that Nanocyl 3100 contains growth catalyst impurities, mainly Fe and Co $(0.19 \%$ and $0.07 \%$, respectively), sulfur $(0.14 \%)$, which is probably due to the purification process, and traces of $\mathrm{Al}(0.03 \%)$.

\subsection{Dye biodegradation}

Biological dye decolourisation assays were conducted in $70 \mathrm{~mL}$ serum bottles, sealed with a butyl rubber stopper, containing $25 \mathrm{~mL}$ of medium. The primary electron donating substrate of the medium was composed of $2 \mathrm{~g} \mathrm{~L}^{-1}$ chemical oxygen demand (COD) of a $\mathrm{NaOH}$-neutralised volatile fatty acids (VFA) mixture, containing acetate, propionate and butyrate in a COD based ratio of 1:10:10. Basal nutrients were also added: $\mathrm{NH}_{4} \mathrm{Cl}\left(2.8 \mathrm{~g} \mathrm{~L}^{-1}\right), \mathrm{CaCl}_{2}$ $\left(0.06 \mathrm{~g} \mathrm{~L}^{-1}\right), \mathrm{KH}_{2} \mathrm{PO}_{4}\left(2.5 \mathrm{~g} \mathrm{~L}^{-1}\right), \mathrm{MgSO}_{4} \cdot 7 \mathrm{H}_{2} \mathrm{O}\left(1 \mathrm{gL}^{-1}\right)$. Medium was buffered at a pH of $7.3 \pm 0.2$ with $\mathrm{NaHCO}_{3}\left(2.5 \mathrm{~g} \mathrm{~L}^{-1}\right)$. Nonadapted anaerobic granular sludge was in the medium at a concentration of $2.5 \pm 0.5 \mathrm{~g} \mathrm{~L}^{-1}$ volatile suspended solids (VSS). The kinetics of azo dye decolourisation were conducted at dye concentrations in the range 0.15 and $4.0 \mathrm{mM}$. The effect of the different carbon materials $\left(\mathrm{AC}_{\mathrm{H} 2}, \mathrm{CXA}, \mathrm{CXB}, \mathrm{CNT}\right)$ on dye decolourisation was tested with dye concentration of $1 \mathrm{mM}$. The amount of carbon materials used, $0.1 \mathrm{gL}^{-1}$, is in accordance with the previous published work [16], in which AC concentrations from $0.1 \mathrm{~g} \mathrm{~L}^{-1}$ to $0.6 \mathrm{~g} \mathrm{~L}^{-1}$ were tested and lead to an increase of the dye adsorption (from less than $10 \%$ to $65 \%$ ), but the decolourisation rates were similar. These results are important once activated carbon is costly and therefore the use of low amounts is an advantage for the application of the biological process. Furthermore, as a redox mediator, AC is cycled from its oxidised and reduced states and thus should be very effective at low concentrations. Sludge was incubated overnight at $37^{\circ} \mathrm{C}$, in a rotary shaker, at $120 \mathrm{rpm}$. After the pre-incubation period, dye and VFA's $\left(2 \mathrm{~g}_{\mathrm{COD}} \mathrm{L}^{-1}\right)$ were added with a syringe from the stock solution to the desired concentration. Controls without carbon material and without biomass were also conducted. All experiments were prepared in triplicate.

In order to evaluate the reutilisation of carbon materials and the efficiency of the process, three cycles, of $24 \mathrm{~h}$, of dye addition, were carried out without carbon material regeneration. VFA's were also added at the beginning of each cycle.

\subsection{Real and model wastewater biodegradation}

Two real effluents were collect from a textile company "Valintece Tecelagem de Malhas, SA" (Fafe, Portugal) after the dying process. The effluent $A$, contained three reactive azo dyes, namely Procion Blue HEXL (PB), Procion Yellow HEXL (PY) and Procion Red HEXL (PR) and the effluent B, contained three other reactive dyes, Remazol Yellow RR (RY), Remazol Brilliant Yellow 3GL (RBY) and Remazol Blue RR (RB). The structures of the dyes, except for RY and $\mathrm{RB}$, are illustrated in Fig. 1. The dyes used in the textile company are all from DyeStar. The industrial water contained also $20 \mathrm{~g} \mathrm{~L}^{-1}$ of sodium chloride and $6 \mathrm{~g} \mathrm{~L}^{-1}$ of sodium carbonate. The $\mathrm{pH}$ was 7.86, for effluent $A$ and 10.11 , for effluent $B$. Except for $\mathrm{pH}$, which was corrected with $\mathrm{NaOH}$ to 7, real wastewaters were treated as supplied by the textile company. Initial absorbance at the $\lambda_{\max }(510 \mathrm{~nm}$, for effluent $A$ and $420 \mathrm{~nm}$, for $B$ ) were 0.5 and 0.15 , respectively.

A model wastewater was prepared by mixing the Procion dyes (obtained from the textile company) at equally concentration, $0.1 \mathrm{~g} \mathrm{~L}^{-1}$, with final absorbance at $510 \mathrm{~nm}$ of 1 . The $\mathrm{pH}$ of the solution was 7 . The effect of salts was also evaluated by preparing a model wastewater containing also $20 \mathrm{~g} \mathrm{~L}^{-1}$ of sodium chloride and $6 \mathrm{~g} \mathrm{~L}^{-1}$ of sodium carbonate. Batch assays were prepared as described in Section 2.3, but containing real or model wastewater instead of the dye solutions. The effect of carbon materials was also investigated at concentration of $0.1 \mathrm{~g} \mathrm{~L}^{-1}$. Controls without $\mathrm{CM}$ were also performed.

\subsection{Activity tests}

Specific methanogenic activity (SMA) tests were performed in serum bottles of $25 \mathrm{~mL}$, containing $12.5 \mathrm{~mL}$ of buffer solution: $3.05 \mathrm{~g} \mathrm{~L}^{-1}$ sodium bicarbonate and $1 \mathrm{~g} \mathrm{~L}^{-1}$ of Resazurin. Vials were supplemented with $0.4 \mathrm{~g}$ anaerobic granular sludge, which corresponds to $2.1 \pm 0.2 \mathrm{~g}$ of volatile suspended solids (VSS) per litre, and the headspace was flushed with a mixture of $\mathrm{N}_{2} / \mathrm{CO}_{2}$ $(80 / 20, v / v)$. The final $\mathrm{pH}$ was $7.2 \pm 0.2$. Following the addition of $0.125 \mathrm{~mol} \mathrm{~L}^{-1} \mathrm{Na}_{2} \mathrm{~S}$, under strict anaerobic conditions, the flasks were incubated overnight at $37^{\circ} \mathrm{C}$ and $120 \mathrm{rpm}$. After that period, the substrate ( $3 \mathrm{~mol} \mathrm{~L}^{-1}$ of ethanol) and the dye solution to be tested were added and the flasks were maintained at $37^{\circ} \mathrm{C}$ and $120 \mathrm{rpm}$ over the entire assay. The pressure was measured every 
60 min by using a hand-held pressure transducer, able of measuring a pressure variation of $\pm 2 \mathrm{~atm}(0-202.6 \mathrm{kPa})$ with a minimum detectable variation of 0.005 bar, corresponding to $0.05 \mathrm{~mL}$ of biogas in a $10 \mathrm{~mL}$ headspace. The assay was finished when the pressure remained stable. Methane content of the biogas was measured by gas chromatography using a Chrompack Haysep Q (80-100 mesh) column (Chrompack, Les Ulis, France), with $\mathrm{N}_{2}$ as carrier gas at $30 \mathrm{~cm}^{3} \mathrm{~min}^{-1}$ and a flame-ionisation detector. Temperatures of the injection port, column, and flame-ionisation detector were 120, 40 and $130^{\circ} \mathrm{C}$, respectively. The values of methane production were corrected for the standard temperature and pressure conditions (STP). In order to determine the activities, the values of pressure (calibrated as an analogical signal in $\mathrm{mV}$ ) were plotted as a function of time and the initial slopes of the methane were calculated. SMA values were determined dividing the initial slope by the VSS content of each vial at the end of the experiment and were expressed

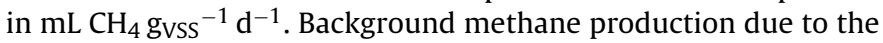
residual substrate was subtracted. Test included series containing increasing dye concentration, in the range of $0.0625-4 \mathrm{mM}$, to evaluate the effect of the dyes on the biomass activity. The effect of the carbon materials, at concentration of $0.1 \mathrm{~g} \mathrm{~L}^{-1}$, on the methanogenic activity was also tested, in the presence and absence of $1 \mathrm{mM}$ dye. Two controls were made in the same conditions, one containing only ethanol (no dye) and the other without any substrate or dye (blank assay). All batch experiments were performed in triplicate. The effect of dye was evaluated by comparing with the control containing only ethanol.

\subsection{Analytical techniques}

Colour decrease was monitored spectrophotometrically in a 96-well plate reader (ELISA BIO-TEK, Izasa). At select intervals, samples were withdrawn $(300 \mu \mathrm{L})$, centrifuged at $5000 \mathrm{rpm}$ for $10 \mathrm{~min}$ to remove the biomass and/or CM, and diluted to obtain less than one absorbance unit. Dilutions were made with ascorbic acid solution in order to avoid products autooxidation. The visible spectra (300-900 nm) were recorded and the dye concentration was calculated at $\lambda_{\max }$. Molar extinction coefficients were calculated for each dye at $\lambda_{\max }: \varepsilon_{350 \mathrm{~nm}}=15.52 \mathrm{mM}^{-1} \mathrm{~cm}^{-1}$ for MY10; $\varepsilon_{510 \mathrm{~nm}}=28.59 \mathrm{mM}^{-1} \mathrm{~cm}^{-1}$ for RR120; $\varepsilon_{480 \mathrm{~nm}}=24.59 \mathrm{mM}^{-1} \mathrm{~cm}^{-1}$ for $A 010$ and $\varepsilon_{510 \mathrm{~nm}}=22.65 \mathrm{mM}^{-1} \mathrm{~cm}^{-1}$ for the model wastewater.

Colour removal (CR) was calculated according to equation

$\mathrm{CR}(\%)=\left[\frac{A_{0}-A_{t}}{A_{0}}\right] \times 100$,

where $A_{0}$ is the absorbance at $\lambda_{\max }$ of the dye at the beginning of incubation and $A_{t}$, the absorbance at $\lambda_{\max }$ at a selected time $(t)$. First-order reduction rate constants were calculated in OriginPro 6.1 software, applying the equation

$C_{t}=C_{0}+C_{i} e^{-k t}$,

where $C_{t}$ is the concentration at time $t ; C_{0}$, the offset; $C_{i}$, the concentration at initial time; $k$, the first-order rate constant $\left(\mathrm{d}^{-1}\right)$ and $t$ is the accumulated time of the experiment.

HPLC analyses were performed in a HPLC (JASCOAS2057 Plus) equipped with a DAD (Diode Array Detector) detector. A C18 reverse phase Nucleodur MNC18 column $(250 \mathrm{~mm} \times 9 \mathrm{~mm} \times 4.0 \mathrm{~mm}, 5 \mu \mathrm{M}$ particle size and pore of $100 \AA$ from Machenerey-Nagel, Switzerland) was used. Mobile phase was composed of two solvents: A (1\% of acetic acid solution, $\mathrm{pH} 3.5$ ) and $\mathrm{B}$ (acetonitrile, $\mathrm{ACN}$ ). Compounds were eluted at a flow rate of $0.5 \mathrm{~mL} \mathrm{~min}^{-1}$ and at room temperature, with isocratic condition of $0 \%$ of ACN over $10 \mathrm{~min}$, followed of an increased from $0 \%$ to $80 \%$ $\mathrm{ACN}$, during $20 \mathrm{~min}$, and remaining in this conditions more $6 \mathrm{~min}$.
Table 1

Properties of the prepared carbon material samples.

\begin{tabular}{llllc}
\hline Sample & $S_{\mathrm{BET}}\left(\mathrm{m}^{2} \mathrm{~g}^{-1}\right)$ & $S_{\text {meso }}\left(\mathrm{m}^{2} \mathrm{~g}^{-1}\right)$ & $V_{\text {micro }}\left(\mathrm{cm}^{3} \mathrm{~g}^{-1}\right)$ & $d_{\mathrm{BJH}}{ }^{\mathrm{a}}(\mathrm{nm})$ \\
\hline $\mathrm{AC}$ H2 & 987 & 129 & 0.377 & - \\
$\mathrm{CXA}$ & 540 & 168 & 0.192 & 3.2 \\
$\mathrm{CXB}$ & 566 & 233 & 0.165 & 24.4 \\
$\mathrm{CNT}$ & 331 & 331 & 0 & - \\
\hline
\end{tabular}

a Average mesopore diameter obtained by the Barret, Joyner and Halenda (BJH) method applied to the desorption isotherm.

Compounds elution was monitored at $\lambda_{\max }$ of dyes and at $\lambda_{\max }$ of the standards ( $250 \mathrm{~nm}$ for SA and $300 \mathrm{~nm}$ for 5-ASA).

\section{Results and discussion}

\subsection{Characterisation of carbon materials}

Selected properties of the prepared materials are presented in Tables 1 and 2 .

Characterisation of the thermal modified $\mathrm{AC}$ sample, $\mathrm{AC}_{\mathrm{H} 2}$, was previously reported [16]. Thermal treatments at high temperature produce materials with low amount of oxygen containing surface groups and high basicity, resulting mainly from some ketonic groups remaining on the surface, from the low amount of acidic groups, and from the delocalised $\pi$-electrons of the carbon basal planes. These electrons are responsible for the high basicity of the $\mathrm{AC}_{\mathrm{H} 2}$ sample. Compared with the other $\mathrm{CM}$ prepared, this sample is characterised by the presence of micropores and by the higher surface area.

Characterisation of the mesoporous materials tested, carbon xerogels and carbon nanotubes, was previous reported $[18,19]$. The main differences among the carbon xerogels (CX) prepared at different initial pHs are in the average mesopore diameter. The carbon xerogel prepared at $\mathrm{pH} 5.45, \mathrm{CXB}$, has the largest mesopore size $\left(d_{\mathrm{BJH}}=24.4\right.$ and $3.2 \mathrm{~nm}$ for $\mathrm{CXB}$ and $\mathrm{CXA}$, respectively). Contrary to the carbon xerogel samples that have cylindrical pores, the mesoporosity of the CNT sample results from the free space in the CNT bundles, with a pore size distribution between 10 and $24 \mathrm{~nm}$ [19]. This type of pore structure facilitates the access of large molecules to the carbon surface. CNT sample presents lower oxygen-containing surface groups, especially CO releasing groups.

\subsection{Kinetics of dye biodegradation}

Different classes of dyes, acid (AO10), mordant (MY10) and reactive (RR120), were tested for anaerobic colour removal. As monitored by spectrophotometry, a decrease in the intensity of the maximum absorption band was observed for MY10 and RR120 (data not shown). Maximum colour removals were obtained after $3 \mathrm{~h}$ for MY10 and $9 \mathrm{~h}$ for RR120, being $83 \pm 1 \%$ and $67 \pm 3 \%$, respectively. No further colour decrease was detected in $24 \mathrm{~h}$ of monitoring. The acid dye, AO10, was not biodegraded. The kinetics of MY10 and RR120 biodegradation were studied at different initial dye concentrations (range from $0.15 \mathrm{mM}$ to $4 \mathrm{mM}$ ). Similar behaviour was observed for both dyes, with first-order rates

Table 2

Textural and chemical characterisation of prepared carbon materials.

\begin{tabular}{llll}
\hline Sample & $\mathrm{CO}_{2}{ }^{\mathrm{a}}\left(\mu \mathrm{molg}^{-1}\right)$ & $\mathrm{CO}^{\mathrm{a}}\left(\mu \mathrm{mol} \mathrm{g}^{-1}\right)$ & $\mathrm{CO} / \mathrm{CO}_{2}{ }^{\mathrm{b}}$ \\
\hline $\mathrm{AC}_{\mathrm{H} 2}$ & 59 & 590 & 10 \\
$\mathrm{CNT}$ & 25 & 478 & 19 \\
\hline
\end{tabular}

a Amounts of $\mathrm{CO}$ and $\mathrm{CO}_{2}$ released, obtained by integration of the areas under TPD spectra.

b Mass percentage of oxygen on the surface, obtained from TPD data assuming that all the surface oxygen is released as $\mathrm{CO}$ and/or $\mathrm{CO}_{2}$. 

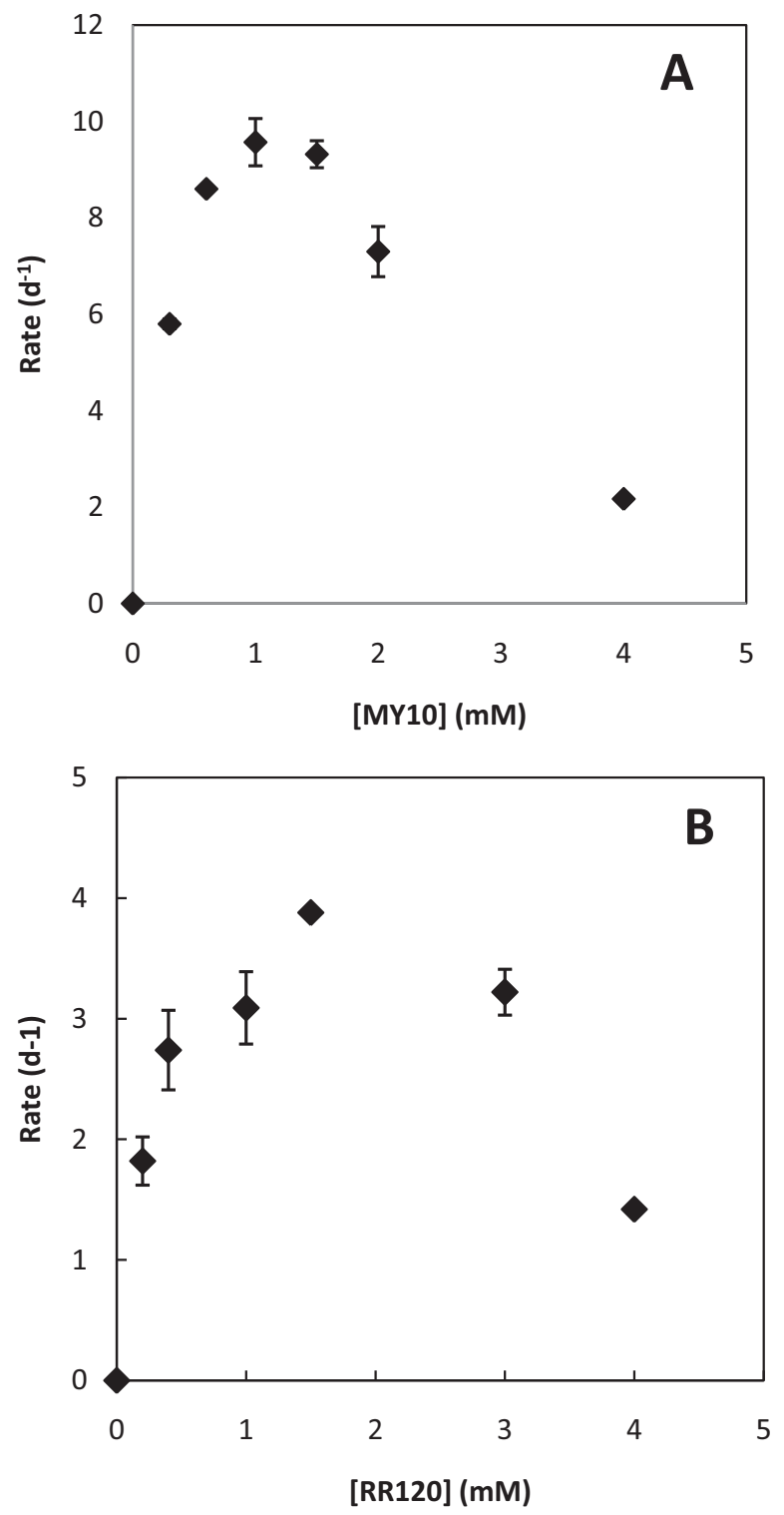

Fig. 2. Kinetics of MY10 (A) and RR120 (B) biodegradation at increasing initial dye concentrations.

increasing with dye concentration up to $1 \mathrm{mM}$ for MY10, and $1.5 \mathrm{mM}$ for RR120, and inhibition at higher concentrations (Fig. 2). In anaerobic processes, dyes are used as final electron acceptor compounds and the co-substrate as electron donors, at higher dye concentrations bacteria can use also dyes as co-substrate and a competition between both substrates may result in kinetics inhibition $[21,22]$. Other possibility may be the toxicity exerted by the dyes when used at high levels and also of the formed products [22]. This possibility is corroborated by the results of activity tests for MY10. An increase of inhibition was also detected with the increase of dye concentration (data not shown). The activity decreased from $1.4 \mathrm{~g} \mathrm{COD}-\mathrm{CH}_{4} \mathrm{gvss}^{-1} \mathrm{~d}^{-1}$, with $1 \mathrm{mM}\left(366 \mathrm{mg} \mathrm{L}^{-1}\right)$ of dye, to $0.94 \mathrm{gCOD}-\mathrm{CH}_{4} \mathrm{gvss}^{-1} \mathrm{~d}^{-1}$, with $4 \mathrm{mM}\left(1465 \mathrm{mg} \mathrm{L}^{-1}\right)$ of dye, corresponding to a decrease of $39 \%$ on biomass activity. In the case of RR120, the activity was not affected by the dye in the range of the tested concentrations. This may be due to the fact that this dye has a bigger structure, being less accessible to the cells. On the other hand, in the presence of AO10, 70\% of methanogenic activity was obtained with all the dye concentrations tested in the range $0.0625 \mathrm{mM}\left(28.3 \mathrm{mg} \mathrm{L}^{-1}\right)$ to $4 \mathrm{mM}\left(1809.5 \mathrm{mg} \mathrm{L}^{-1}\right)$. Anaerobic batch

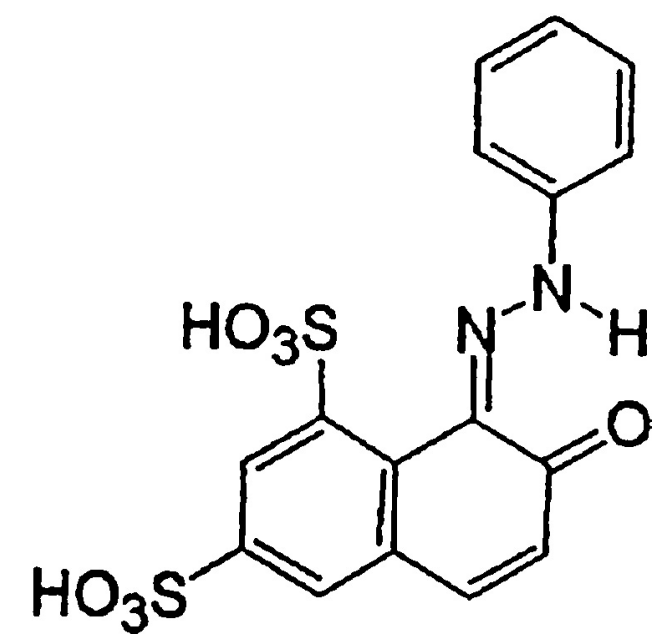

Fig. 3. Molecular structure of Acid Orange 10 in the hydrazone form.

toxicity assays usually do not reveal severe inhibition of methanogenesis at azo dye concentrations below $100 \mathrm{mg} \mathrm{L}^{-1}$, however, at high dye concentrations, decrease of the activity has been reported in some of the reactor studies [23]. It is worth to mention that in dyehouse effluents, dyes are usually present at concentrations of $10-250 \mathrm{mg} \mathrm{L}^{-1}$, depending on the dyes and processes used [24].

Similarly to the extent of decolourisation, also the rates of reaction have varied among the dyes. The maximal rate obtained was almost 2.5-fold higher for the monoazo MY10, $9.50 \pm 0.49 \mathrm{~d}^{-1}$, than for the diazo RR120, $3.88 \pm 0.02 \mathrm{~d}^{-1}$, which has a more complex structure. Dyes with simple structures and low molecular weights are reported to exhibit higher rates of colour removal [25]. Colour removal can also be related, in some cases, to the number of azo bonds in the dye molecule [26]. Reduction rates are also influenced by changes in electron density in the region of the azo group. The substitution of electron withdrawing groups $\left(-\mathrm{SO}_{3} \mathrm{H},-\mathrm{SO}_{2} \mathrm{NH}_{2}\right)$ in the para position of the phenyl ring, relative to the azo bond, has been reported to cause an increase in the reduction rate [16,27], which is the case of MY10. Electron withdrawing groups such as $-\mathrm{OH}$ and $-\mathrm{NH}_{2}$ decrease the electron density around the azo bond and facilitate its reduction [28]. Hydrogen bonding, in addition to the electron density in the region of the azo bond, has a significant effect on the rate of reduction [29]. The position and the nature of substituents on the dye molecule influence the azo-hydrazone tautomerism of hydroxyazo compounds $[30,31]$. The hydroxy proton of phenylazo-naphthol derivatives is labile and can bond with a nitrogen atom of the azo group, causing a rapidly formed tautomeric equilibrium between the azo and hydrozone forms (i.e., $-\mathrm{N}=\mathrm{N}-$, N-NH, Fig. 3 is an example for AO10). Some authors have observed a decreased of reduction rate with substrates that were stabilised in the hydrazone form $[32,33]$. This may contribute for the non biodegradability of AO10. It is worth to note that factors as for example, substituents groups, potential redox or $\mathrm{p} K_{\mathrm{a}}$ of substrates, which are also related to the chemical structure, are also known to play an important role in determining the reaction rates [34].

\subsection{Products and mechanism of azo dye reduction}

Under anaerobic conditions, colour removal is associated with the cleavage of the azo bound, with formation of the correspondent aromatic amines [35-38]. In an attempt to prove that the colour removal is due to the reduction of the dye molecules to the correspondent aromatic amines, the final products of the biodecolourisation of MY10 were identified by HPLC. The absorbance 
of the peak of the dye, with retention time $\left(R_{t}\right) 21 \mathrm{~min}$, decreased over the time reaction and two new peaks at $R_{t} 6.9$ and $8.3 \mathrm{~min}$ were formed (Fig. 4A and B). The products were identified by comparison with authentic standards as sulfanilic acid (SA) and 5-aminosalisiloic acid (5-ASA), respectively (Fig. 4C). According to these results, the mechanism of biodegradation by reduction of azo dye was confirmed (Fig. 4D). The increase of absorbance of the peaks corresponding to the aromatic amines indicates that they are not degraded, but accumulate under anaerobic conditions. These results are in accordance to Brás et al. [36], who have also identified by HPLC the aromatic amine sulfanilic acid from the biodegradation of Acid Orange 7 meaning that SA was not mineralised under anaerobic conditions, in the test conditions. Studies on the biodegradation of SA and 5-ASA by Tan et al. [39], showed that 5-ASA and SA could only be degraded if an inoculum from aerobic enrichment cultures was added to the batch experiments.

\subsection{Carbon materials as catalysts on dye biodegradation}

The extent and rates of decolourisation at the different conditions are set in Table 3. Except for the most recalcitrant dye, AO10, the extent of decolourisation was not affect in the presence of CM. In the case of AO10, not biologically decolourised, the presence of CNT and CXB allowed its almost complete decolourisation, 98\%, proving the effect of redox mediation (Fig. 5). Also the other materials tested $\mathrm{AC}_{\mathrm{H} 2}$ and $\mathrm{CXA}$, lead though at lower extent, $\mathrm{AO} 10$ decolourisation. Additionally, for all the three dyes, rates of biodegradation were higher in the presence of the carbon materials, with better results for CNT and CXB. As compared with the reaction without carbon materials, rates increased 2-fold for MY10 and 1.5-fold for RR120.

The better performance of the mesoporous carbon materials is explained by the easier access of the dye molecules to the surface of the catalyst. In the same way, the higher rates obtained with $\mathrm{CXB}$, synthesised at lower $\mathrm{pH}$, in comparison with $\mathrm{CXA}$, is explained by the larger mesopores obtained in the preparation at lower pH (Table 1), which may allow an easier access of the dye, especially in the case of RR120. Orge et al. [19], have tested different carbon xerogels as catalysts in the ozonation of Reactive Blue 5 and also observed that the catalytic activity of the carbon xerogels increases when the $\mathrm{pH}$ used in the preparation process decreases. In a previous work with microporous activated carbons, higher reduction rates were obtained with the thermal treated sample (sample $\mathrm{AC}_{\mathrm{H} 2}$ ) and was related with the a high content of electron rich sites on their basal planes (electrons $\pi$ ), known to be active sites, and by a low concentration of electron withdrawing groups [16]. CNT are also characterised by lower oxygen-containing surface groups (Table 2) and high amount of delocalised $\pi$ electrons on the surface. Other carbonaceous materials have been reported as redox mediators. As example, graphene was found as a good redox mediator for the reductive transformation of nitroaromatic compounds, increasing two orders of magnitude the abiotic $\left(\mathrm{Na}_{2} \mathrm{~S}\right)$ reduction of nitrobenzene [40]. Similarly to other carbon materials such as the nanotubes, this electron transfer enhancement was attributed to the existence of delocalised $\pi$ electrons and the zigzag edges carbons. However, this high increase of the rate as, cannot be directly compared with our results once biotic reactions are more complex. The effect of modified activated carbon fibres as redox mediators for the abiotic $\left(\mathrm{Na}_{2} \mathrm{~S}\right)$ reduction of nitroaromatic compounds, was also studied by Amezquita-Garcia et al. [41]. Authors have reported that the presence of those materials is a requisite for the reduction of 4-nitrophenol and 3-chlolonitrobenzene, which was attributed to the quinone groups present in the carbon materials.

The presence of carbon materials did not affect the methanogenic activity, which was maintained as compared with the control.
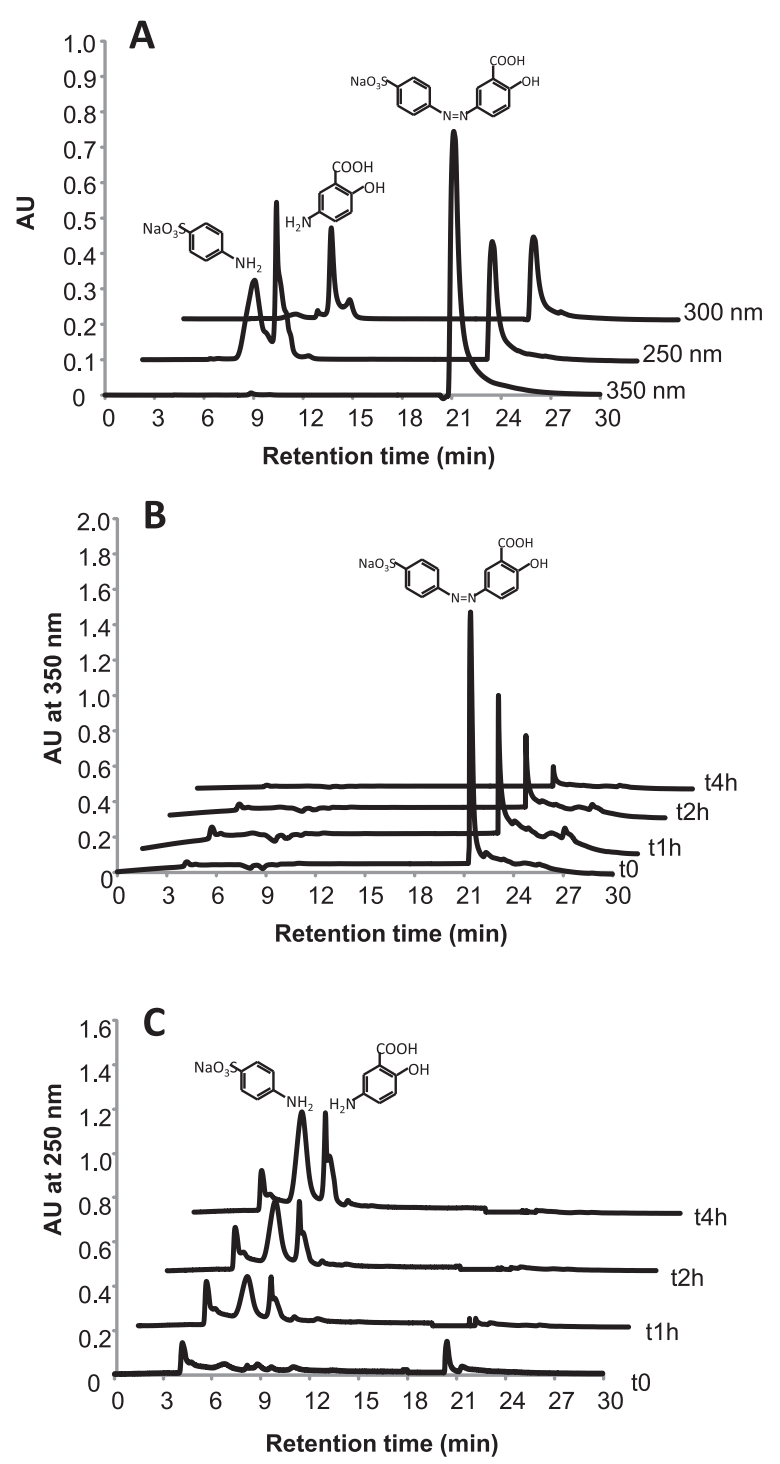

$D$

Azo bound cleavage

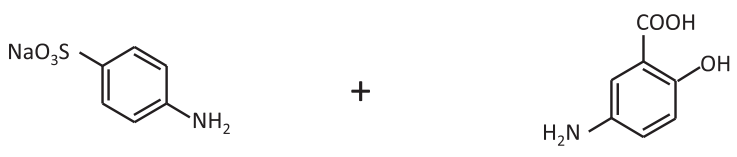

Fig. 4. HPLC chromatograms of the standards MY10, SA and 5-ASA (A) and of the MY10 biodegradation at (B) $350 \mathrm{~nm}$ and (C) $250 \mathrm{~nm}$. (D) Mechanism of MY10 biodegradation with formation of the correspondent aromatic amines. 
Table 3

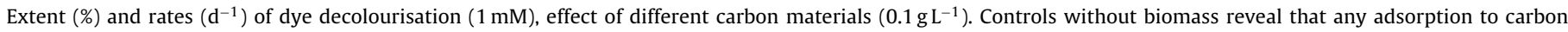
materials occurs (data not shown).

\begin{tabular}{|c|c|c|c|c|c|c|}
\hline \multirow[t]{2}{*}{ Sample } & \multicolumn{2}{|l|}{ MY10 } & \multicolumn{2}{|l|}{ RR120 } & \multicolumn{2}{|l|}{ A010 } \\
\hline & $\%$ & $\mathrm{~d}^{-1}$ & $\%$ & $\mathrm{~d}^{-1}$ & $\%$ & $\mathrm{~d}^{-1}$ \\
\hline No CM & $83 \pm 1$ & $9.50 \pm 0.49$ & $67 \pm 3$ & $3.09 \pm 0.30$ & 0 & 0 \\
\hline $\mathrm{AC}_{\mathrm{H} 2}$ & $85 \pm 1$ & $11.02 \pm 0.68$ & $68 \pm 3$ & $3.15 \pm 0.04$ & $46 \pm 5$ & $2.07 \pm 0.24$ \\
\hline CXA & $85 \pm 1$ & $11.11 \pm 0.44$ & $73 \pm 1$ & $3.78 \pm 0.19$ & $67 \pm 1$ & $2.72 \pm 0.13$ \\
\hline CXB & $85 \pm 1$ & $14.99 \pm 0.18$ & $75 \pm 2$ & $4.54 \pm 0.67$ & $98 \pm 2$ & $4.48 \pm 0.74$ \\
\hline CNT & $86 \pm 1$ & $20.08 \pm 1.14$ & $75 \pm 2$ & $4.01 \pm 0.28$ & $98 \pm 2$ & $3.16 \pm 0.65$ \\
\hline
\end{tabular}

Table 4

Extent (\%) and rates $\left(\mathrm{d}^{-1}\right)$ of MY10 decolourisation ( $\left.1 \mathrm{mM}\right)$, during 3 cycles of dye addition.

\begin{tabular}{|c|c|c|c|c|c|c|}
\hline \multirow[t]{2}{*}{ Sample } & \multicolumn{2}{|c|}{ 1st cycle } & \multicolumn{2}{|c|}{ 2nd cycle } & \multicolumn{2}{|c|}{ 3rd cycle } \\
\hline & $\%$ & $\mathrm{~d}^{-1}$ & $\%$ & $\mathrm{~d}^{-1}$ & $\%$ & $\mathrm{~d}^{-1}$ \\
\hline No CM & $83 \pm 1$ & $9.50 \pm 0.49$ & $89 \pm 2$ & $9.55 \pm 0.30$ & $90 \pm 1$ & $6.44 \pm 0.46$ \\
\hline $\mathrm{CXB}$ & $85 \pm 1$ & $14.99 \pm 0.18$ & $90 \pm 1$ & $14.20 \pm 0.41$ & $86 \pm 2$ & $9.31 \pm 0.09$ \\
\hline CNT & $86 \pm 1$ & $20.08 \pm 1.14$ & $92 \pm 1$ & $16.14 \pm 0.52$ & $88 \pm 1$ & $10.81 \pm 0.59$ \\
\hline
\end{tabular}

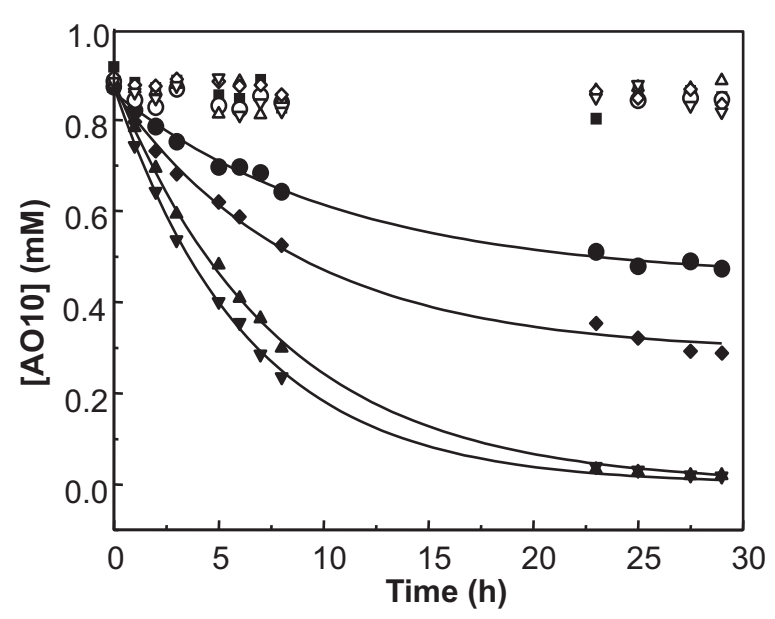

Fig. 5. First-order rate curves of $\mathrm{AO} 10$ (A) biodegradation. $\mathbf{\square}$, no carbon material; $\bullet$, $\mathrm{AC}_{\mathrm{H} 2}, \mathrm{CXA} ; \mathbf{\wedge}, \mathrm{CXB}$ and $\mathbf{\nabla}, \mathrm{CNT}$. Black symbols correspond to the biotic and white symbols to the abiotic assays.

Three cycles of fresh MY10 solution addition were carried out with the objective of evaluating the reutilisation of carbon materials. Although a decrease of the rates during the cycles was observed, effects as redox mediator was still present (Table 4). The decrease of the efficiency of the CM may be, in part, due to fact that the new cycles were performed with the materials from the previous experiment, without carbon material regeneration. Additionally, a decrease of the efficiency was also observed in the experiments without CM.

\subsection{Textile wastewater treatment}

With the aim of testing the process in a real textile wastewater, biodecolourisation of two real effluents, effluent A and effluent $B$, was performed in the same conditions as for the single dyes. A model wastewater prepared by the mixture of the three dyes that constitute the real effluent $\mathrm{A}$ was also treated. Effluent $\mathrm{A}$ was decolourised within $24 \mathrm{~h}$ at the extent of $63 \%$ and at the rate $0.59 \mathrm{~d}^{-1}$ (Table 5). The presence of CNT leads to an increase of the rate to $0.72 \mathrm{~d}^{-1}$. With the other carbon materials, $\mathrm{AC}_{\mathrm{H} 2}, \mathrm{XA}$ and $\mathrm{XB}$, rates and degree of decolourisation were not affected. The effect of CNT was also observed with the Effluent B, which was only decolourised in the presence of CNT, although at lower extent, $32 \%$. Similarly with the observation for the single dyes, this result
Table 5

Extent (\%) and rates $\left(\mathrm{d}^{-1}\right)$ of real and model wastewaters biodecolourisation in the absence and presence of carbon nanotubes $\left(0.1 \mathrm{~g} \mathrm{~L}^{-1}\right)$.

\begin{tabular}{lrllll}
\hline Wastewater & \multicolumn{2}{l}{ No CNT } & & \multicolumn{2}{l}{ CNT } \\
\cline { 2 - 3 } \cline { 5 - 6 } & $\%$ & & $\mathrm{~d}^{-1}$ & & $\mathrm{~d}^{-1}$ \\
\hline Effluent A & $63 \pm 2$ & $0.59 \pm 0.07$ & & $63 \pm 3$ & $0.72 \pm 0.07$ \\
Effluent B & 0 & 0 & & $32 \pm 1$ & $6.01 \pm 0.69$ \\
Model effluent & $97 \pm 1$ & $2.25 \pm 0.20$ & & $97 \pm 1$ & $2.71 \pm 0.32$ \\
\hline
\end{tabular}

Table 6

Extent $(\%)$ and rates $\left(\mathrm{d}^{-1}\right)$ of Procion dyes $(1 \mathrm{mM})$ biodegradation.

\begin{tabular}{llr}
\hline Dye & $\%$ & \multicolumn{1}{c}{$\mathrm{d}^{-1}$} \\
\hline PB & $83 \pm 1$ & $91.2 \pm 2.4$ \\
PY & $89 \pm 2$ & $8.0 \pm 2.8$ \\
PR & $90 \pm 2$ & $1.7 \pm 0.1$ \\
\hline
\end{tabular}

reflects the effect of dyes structure, once the two effluents only differ in the dye composition. Comparing the effluent A with the model wastewater, almost totally decolourised, $97 \%$, and at 4 -fold higher rate, is proved that the presence of salts and other additives that composed the real effluent, affected the biological reaction. The application of CNT, though the same extent of decolourisation, lead also to an improvement of the catalytic rate. The effect of salts was investigated and the extent of decolourisation, after $24 \mathrm{~h}$, was $88 \%$ and the rate decreased 1.5 fold. However, no information about the other additives that compose the real wastewater, such as anti-foamers, detergents, dispersants, surfactants, retardants, etc., could be obtained from the textile company, which may also contribute for the lower performance of biodegradation [42]. In addition, the proportion of each dye in the real effluent was also not provided. Decolourisation of the single Procion dyes that composed the wastewaters was also done (Table 6). All the three Procion dyes were almost totally decolourised, $\sim 90 \%$, though at different rates (Table 6).

\section{Conclusions}

Efficiency of microporous $\left(\mathrm{AC}_{\mathrm{H} 2}\right)$ and mesoporous carbons (CXA, CXB and CNT) as redox mediators on azo dye and real textile wastewater reduction was studied and compared. This is the first report on the use of CX and CNT as redox mediators for azo dye decolourisation. Results demonstrate that the presence of carbon materials increases the reduction rates. Additionally, the presence of carbon material is a requisite for biodegradation of the dye AO10. 
Pore sizes of the chosen carbon material play a key role on dye decolourisation and higher efficiency was obtained for the carbon materials having larger pores. In general, rates increased in the order: control $<\mathrm{AC}_{\mathrm{H} 2}<\mathrm{XA}<\mathrm{XB}<\mathrm{CNT}$. HPLC analysis confirmed the reduction of dyes with the corresponding aromatic amines formation. Results of real wastewater biological treatments demonstrate that the process can successfully be applied on textile wastewaters remediation.

\section{Acknowledgements}

R. Pereira holds a fellowship (SFRH/BD/72388/2010) and L. Pereira holds a Pos-Doc fellowship (SFRH/BPD/80941/2011) from Fundação para a Ciência e Tecnologia.

Acknowledges to the textile company "Valintece Tecelagem de Malhas, SA" (Fafe, Portugal) for the supplying of dyed textile wastewaters.

\section{References}

[1] N. Puvaneswari, J. Muthukrishnan, P. Gunasekaran, Indian Journal of Experimental Biology 44 (2006) 618-626.

[2] L. Pereira, M.M. Alves, in: A. Malik, E. Grohmann (Eds.), Protection Strategies for Sustainable Development, Springer, Dordrecht, 2012, pp. 111-162.

[3] K.T. Chung, S.E.J. Stevens, C.E. Cerniglia, Critical Reviews in Microbiology 18 (1992) 175-197.

[4] H.M. Pinheiro, E. Touraud, O. Thomas, Dyes and Pigments 61 (2004) $121-139$.

[5] I.K. Kapdan, F. Kargi, Enzyme and Microbial Technology 30 (2002) 195-199.

[6] S. Sandhaya, S. Padmavathy, K. Swaminathan, Y.V. Subrahmanyam, S.N. Kaul, Process Biochemistry 40 (2005) 885-890.

[7] K. Eltaief, G. Hana, T. Youssef, B. Hassib, H. Moktar, Journal of Hazardous Materials 52 (2) (2008) 683-689.

[9] X. Lu, B. Yang, J. Chen, R. Sun, Journal of Hazardous Materials 161 (2009) 241-245.

[10] S. Wijetunga, L. Xiufen, R. Wenquan, J. Chen, Bioresource Technology 99 (2008) 3692-3699.

[11] Q. Yang, C. Li, H. Li, Y. Li, N. Yu, Biochemical Engineering Journal 43 (3) (2009) 225-230.

[12] Y. Liu, J.H. Tay, Biotechnology Advances 22 (2004) 533-563.

[13] F.P. Van der zee, R.H. Bouwnman, D.P.B.T.B. Strik, G. Lettinga, J.A. Field, Biotechnology and Bioengineering 75 (2001) 691-701.

[14] F.P. Van der Zee, F.J. Cervantes, Biotechnology Advances 27 (2009) 256-277.
[15] G. Mezohegyi, F. Gonçalves, J.J.M. Órfão, A. Fabregat, A. Fortuny, J. Font, C. Bengoa, F. Stuber, Applied Catalysis B: Environmental 94 (2010) 179-185.

[16] L. Pereira, R. Pereira, M.F.R. Pereira, F.P. Van der Zee, F.J. Cervantes, M.M. Alves, Journal of Hazardous Materials 183 (2010) 931-939.

[17] F.P. Van der Zee, I.A. Bisschops, G. Lettinga, J.A. Field, Environmental Science and Technology 37 (2003) 402-408.

[18] A.G. Gonçalves, J.L. Figueiredo, J.J.M. Órfão, M.F.R. Pereira, Carbon 48 (2010) 4369-4381.

[19] C.A. Orge, J.J.M. Órfão, M.F.R. Pereira, Applied Catalysis B: Environmental 126 (2012) 22-28.

[20] J.P. Tessonnier, D. Rosenthal, T.W. Hansen, C. Hess, M.E. Schuster, R. Blume, F. Girgsdies, N. Pfänder, O. Timpe, D.S. Su, R. Schlögl, Carbon 47 (7) (2009) 1779-1798.

[21] M. Ișık, D.T. Sponza, Chemosphere 55 (2004) 119-128.

[22] M. Işık, D.T. Sponza, Journal of International Environmental Application and Science $1(1-2)(2006) 1-26$.

[23] F.P. Van der Zee, S. Villaverde, Water Research 39 (2005) 1425-1440.

[24] C. O'Neill, F.R. Hawkes, D.L. Hawkes, N.D. Lourenco, H.M. Pinheiro, W. Deleé, Journal of Chemical Technology and Biotechnology 74 (1999) 1009-1018.

[25] R.K. Sani, U.C. Banerjee, Enzyme and Microbial Technology 24 (1999) 433-437.

[26] T.-L. Hu, Water Science and Technology 43 (2) (2001) 261-269.

[27] C.I. Pearce, J.R. Lloyd, J.T. Guthrie, Dyes and Pigments 58 (2003) 179-196.

[28] P. Nigam, I.M. Banat, D. Singh, R. Marchant, Process Biochemistry 31 (5) (1996) 435-442.

[29] M.I. Beydilli, S.G. Pavlostathis, W.C. Tincher, Water Environment Research 72 (6) (2000) 698-705.

[30] C.-C. Hsueh, B.-Y. Chen, C.-Y. Yen, Journal of Hazardous Materials 167 (2009) 995-1001.

[31] A.S. Özen, P.D.V. Aviyente, Journal of Physical Chemistry A 111 (2007) 13506-13514.

[32] T. Zimmerman, H.G. Kulla, T. Leisinger, European Journal of Biochemistry 129 (1982) 197-203.

[33] P.A. Ramalho, M.H. Cardoso, A. Cavaco-Paulo, M.T. Ramalho, Applied and Environment Microbiology 70 (4) (2004) 2279-2288.

[34] H. Chen, Current Protein and Peptide Science 7 (2006) 101-111.

[35] L. Pereira, A.V. Coelho, C.A. Viegas, M.M.C. Dos Santos, M.P. Robalo, L.O. Martins, Journal of Biotechnology 139 (2009) 68-77.

[36] R. Brás, A. Gomes, M.I.A. Ferra, H.M. Pinheiro, I.C. Gonçalves, Journal of Biotechnology 115 (2005) 57-66.

[37] S. Mendes, L. Pereira, C. Batista, L.O. Martins, Applied Microbiology and Biotechnology 92 (2011) 393-405

[38] P.A. Ramalho, H. Scholze, M.H. Cardoso, M.T. Ramalho, A.M. Oliveira-Campos, Enzyme and Microbial Technology 31 (2002) 848-854.

[39] N.C.G. Tan, F.X. Prenafeta-Bolduâ, J.L. Opsteeg, G. Lettinga, J.A. Field, Applied Microbiology and Biotechnology 51 (1999) 865-871.

[40] H. Fu, D. Zhu, Environmental Science and Technology 47 (2013) 4204-4210.

[41] H.J. Amezquita-Garcia, E. Razo-Flores, F.J. Cervantes, J.R. Rangel-Mendez, Carbon 55 (2013) 276-284.

[42] F. Zhang, A. Yediler, X. Liang, A. Kettrup, Dyes and Pigments 60 (2004) 1-7. 